\title{
Aspects of Peltophorum dubium Sprengel (Taubert) seeds in an aerial seed bank ${ }^{1}$
}

\author{
Girlânio Holanda Silva ${ }^{2 *}$, Anderson Cleiton José ${ }^{3}$, \\ José Marcio Rocha Faria ${ }^{3}$, Wilson Vicente Souza Pereira ${ }^{3}$
}

\begin{abstract}
Knowledge concerning natural regeneration strategies is important due to the effect of natural regeneration on the local ecosystem. The aim of this study was to examine the ecophysiological aspects of the Peltophorum dubium aerial seed bank. Fruits were harvested monthly, before and after seed maturation, from selected trees in the municipality of Lavras, MG, Brazil, for determination of moisture content, acquisition of tolerance to desiccation, seed viability, maintenance of dormancy, and mean germination time. Physiological maturity of the species was attained in June, when low moisture content, maximum dry matter, and high germination percentage were observed. We found that there was no change in dormancy, in germination percentage, or in the protein profile of seeds during the period they remained in the aerial seed bank. The $P$. dubium species creates an aerial seed bank of short serotiny, with fruits remaining attached to the tree for 9 months.
\end{abstract}

Index terms: serotiny, seed longevity, seed vigor, angico-amarelo

\section{Comportamento de sementes de Peltophorum dubium Sprengel (Taubert) em banco de sementes aéreo}

RESUMO - O conhecimento sobre estratégias de regeneração natural é importante devido a sua influência no ecossistema local. Objetivou-se estudar o comportamento do banco de sementes aéreo de P. dubium. Os frutos foram colhidos mensalmente antes e após a maturação das sementes em matrizes localizadas no município de Lavras - MG. Mensalmente, foram determinados o conteúdo de água, aquisição da tolerância a dessecação, viabilidade das sementes, manutenção da dormência e tempo médio de germinação. Verificou-se que a maturidade fisiológica da espécie ocorreu no mês de junho, quando foi observado baixo conteúdo de água, máxima matéria seca, e alta porcentagem de germinação. Verificou-se que não houve alteração na dormência, porcentagem de germinação e no perfil proteico de sementes durante o período em que permanecem no banco de sementes aéreo. A espécie $P$. dubium forma banco de sementes aéreo de curta serotinosidade, com frutos permanecendo presos à planta por 9 meses.

Termos de indexação: serotinosidade, longevidade, vigor, angico-amarelo.

\section{Introduction}

Native forests make use of diverse regeneration strategies for the purpose of maintaining resilience after being disturbed, ensuring the continuity of ecophysiological processes (Tonello and Teixeira Filho, 2012). Thus, knowledge of strategies of forest species becomes important to understand processes such as colonization, which is fundamental for planning and restoration of forest ecosystems (Albuquerque et al., 2010; Guimarães et al., 2014).

Among the best-known plant establishment strategies are vegetative reproduction, seed rain, and soil seed and seedling bank (Braga et al., 2015; Durigan et al., 2011; Miranda Neto

${ }^{1}$ Submitted on 08/30/2016. Accepted for publication on 12/15/2016.

${ }^{2}$ Universidade Estadual Paulista, Júlio de Mesquita Filho, UNESP, Caixa Postal 237, 18610-307 - Botucatu, SP, Brasil. et al., 2010). However, there are other species that have littleknown regeneration strategies, such as delay in seed dispersal. These species maintain viable seeds attached to the mother plant for at least three months after reaching physiological maturity, forming the aerial seed bank (Baskin and Baskin, 2014). The length of time seeds remain in the aerial seed bank depends on the species, as was observed in species from the northern hemisphere (Bastida et al., 2010; Teste et al., 2011).

Species that form aerial seeds banks are called "serotinous" species, which fall into two classifications: species with short serotiny, when seed dispersal is delayed for up to one year, and those with long serotiny, which maintain seeds in the aerial seed bank for periods exceeding one year. In addition,

${ }^{3}$ Departamento de Ciências Florestais, Universidade Federal de Lavras, Caixa Postal 3037, 37200-000 - Lavras, MG, Brasil.

*Corresponding author < girlanio_holanda@hotmail.com> 
the serotiny of the species is associated with regions subject to fire, dry climate, and low rainfall (Lamont et al., 1991; Wenk and Falster, 2015).

The species $P$. dubium is an arborial Fabaceae popularly known as canafistula and angico-amarelo, considered as a rapid growth pioneer species, with a great deal of potential for reforestation (Bertolini et al., 2015). With only one field guide report (Lorenzi, 2002), it was observed that the fruit of this species can remain attached to the plant; however, without any study of seed quality. Thus, characterization of seed quality and the length of time fruit remains attached to the mother plant can indicate that the species is serotinous, which would provide added ecological value to the species $P$. dubium since serotiny increases the recruitment of individuals to the environment (Gao et al., 2014). In Brazil, however, the only species described as forming an aerial seed bank is Parkia pendula (Oliveira et al., 2006).

Proteins are the main reserve components of the seeds of various leguminous plants, such that there is a tendency for these reserves to be used for maintaining seed vigor (Wang et al., 2015a; Wang et al., 2015b; Wu et al., 2011) up to their dispersal; a reduction in protein content can occur as of that point (Kalemba and Pukacka, 2008). Nevertheless, the literature has not reported if this type of response occurs in serotinous seeds.

Consequently, the present study was carried out with the objective of characterizing the aerial seed bank of $P$. dubium through analysis of possible changes in the physiological quality of seeds.

\section{Materials and Methods}

Four $P$. dubium trees were selected for the monthly collections between April 2014 and February 2015 on a private property in the rural area of the municipality of Lavras, $\mathrm{MG}$, Brazil, at the geographic coordinates $21^{\circ} 15^{\prime} 54^{\prime}$ 'S and $45^{\circ} 01^{\prime}$ $30^{\prime \prime} \mathrm{W}$. The criteria for selection of the trees were uniformity of fruit maturation, verified by the coloring of the fruit (dark brown) and beginning of its natural dispersal (Aquino et al., 2006), absence of fruit from the previous harvest, abundance of fruit for monthly collections made up to the end of the dispersal period, minimum distance of 50 meters between the trees, and plant health appearance (absence of fungi and insects).

After each collect, the seed were manually processed, removing the seeds from the fruit, and they were immediately used in physiological evaluations.

Physiological maturity of the fruit was identified at four stages of maturity: April, March, June and July. The fruit in April was green, but in the following months had a brown color (Aquino et al., 2006). Analyses of germination, moisture content, and tolerance to desiccation were performed monthly. Soon after determination of the point of physiological maturity, the aerial seed bank was characterized and the ecophysiological aspects were monitored through germination and physical dormancy of the seeds; moisture content (Brasil, 2009) and mean germination time (MGT) were also monitored (Labouriau, 1983).

The $P$. dubium seeds were germinated in a roll of paper, with four replications of 25 seeds per sampling point. As of May, when the hard seed coat appeared, before each test, physical seed dormancy was broken, which consisted of cutting the seed coat (approximately $1 \mathrm{~mm}$ ) with a blade on the side opposite the micropyle.

After dormancy was broken, the seeds were immersed in a $1 \%$ sodium hypochlorite solution for three minutes, and immediately after, they were washed in running water for one minute. The experiment was conducted in a B.O.D. germination chamber with four white fluorescent lights regulated at $25{ }^{\circ} \mathrm{C}$ and with a 12-hour photoperiod. The seeds were evaluated daily up to the $7^{\text {th }}$ day. Radicle protrusion $(\geq 1.0 \mathrm{~mm}$ ) was considered as the germination criterion.

Seeds collected during development in the months of April and May were used to study tolerance to desiccation. To do so, soon after collection, the seeds were dried in a controlled environment $\left(40 \% \mathrm{RH}\right.$ and $\left.20{ }^{\circ} \mathrm{C}\right)$ for 72 hours. After this period, the germination test was carried out, using four replications of 25 seeds (Silva et al., 2012). Seeds that were not dried were used as a control.

In analysis of possible change in physical dormancy of the seeds in the aerial seed bank, the collected seeds were placed to germinate after treatment with sodium hypochlorite under the same conditions described above (in a roll of paper, $25^{\circ} \mathrm{C}$, and with 12-h photoperiod), without, however, performing any treatment for breaking dormancy. As a control for this analysis, seeds that went through the treatment for breaking dormancy (cutting the seed coat on the side opposite the micropyle with a blade) were used.

For determination of moisture content, soon after the fruit was collected and processed, the fresh weight of the seeds was obtained on an analytical balance $(0.0001 \mathrm{~g})$. They were then placed in a laboratory oven at $105{ }^{\circ} \mathrm{C}$ for 24 hours and once more weighed to obtain dry matter and determine moisture content (Brasil, 2009). Four replications of five seeds were used, according to the methodology adapted from Aquino et al. (2006). Beginning in April, when the hard seed coat appeared, before determination of moisture content, the seeds were cut in half before being placed in the laboratory oven.

In each one of the sampling points analyzed, a 50 seed 
sample was instantly frozen in liquid nitrogen and stored in an ultrafreezer at $-80{ }^{\circ} \mathrm{C}$, and these samples were used for analysis of changes in the protein profile of $P$. dubium seeds. For extraction, 100 milligrams of whole seeds were macerated in $1 \mathrm{~mL}$ of extraction buffer $(500 \mathrm{mM}$ of Tris $\mathrm{HCl} \mathrm{pH} \mathrm{7.5,} 5 \mathrm{mM}$ of $\mathrm{NaCl}, 5 \mathrm{mM}$ of $\mathrm{MgCl}_{2}, 0.001 \mathrm{M}$ of protease inhibitor [SIGMA FAST ${ }^{\mathrm{TM}}$ PROTEASE] and $1 \mu \mathrm{L}$ of $\beta$-mercaptoethanol). The samples were centrifuged for 30 minutes at $13.200 \mathrm{~g}$ at $4{ }^{\circ} \mathrm{C}$. After that, the supernatant was divided into two subsamples. The first (total proteins) was kept on ice, while the second (heat-resistant proteins) was kept in a water bath for 15 minutes at $85{ }^{\circ} \mathrm{C}$. After that, both subsamples were centrifuged at $13.200 \mathrm{~g}$ for 30 minutes at $4{ }^{\circ} \mathrm{C}$ and the supernatant was collected in $100 \mu \mathrm{L}$ aliquots and stored in a freezer at $20{ }^{\circ} \mathrm{C}$. The extracts were quantified by the Bradford (1976) method, and the values were used as a basis for electrophoresis.

Electrophoresis was performed in discontinuous polyacrylamide gel $(1 \mathrm{~mm})$ at the concentration of $12.5 \%$ (separating gel) and 6\% (stacking gel). For the aliquots of total proteins, the volume of extract needed to obtain $40 \mu \mathrm{g}$ of proteins was calculated. For the aliquots of heat-resistant proteins, the same volume used for the respective aliquot of total proteins was used. The quantity of $25 \mu \mathrm{L}$ of loading buffer was added to these samples, and they were heated at $95^{\circ} \mathrm{C}$ for five minutes before beginning electrophoresis.

Electrophoresis was carried out in vertical unit SE600 (Hoefer) at $160 \mathrm{~V}$ for 7 hours at $15{ }^{\circ} \mathrm{C}$. After running, the gel was fixed in a solution containing $40 \%$ methanol and $7 \%$ acetic acid for 30 minutes and stained for 72 hours in solution with $0.08 \%(\mathrm{w} / \mathrm{v})$ of Coomassie Blue G-250 containing $1.6 \%$ (v/v) orthophosphoric acid and $12 \%(\mathrm{w} / \mathrm{v})$ ammonium sulfate. After that, the gels were decolored in $0.26 \%(\mathrm{w} / \mathrm{v})$ solution of Trizma base $\mathrm{pH} 6.5$, with final washing in $40 \%$ (v/v) methanol solution for one minute. The gels were kept in ultrapure water for 72 hours, at which time they were stored at $5{ }^{\circ} \mathrm{C}$ in acetic acid solution (5\%). The gels were scanned in the high resolution Immage Scan III scanner using the LabScan 6.0 software.

In data analysis, the rainfall and mean monthly temperatures of all the collection periods were obtained from the weather station $1 \mathrm{~km}$ from the area of the experiment. The climate data were used as additional information to assist in understanding and discussion of the results.

To study seed germination during physiological maturity, a completely randomized design was used, with four stages of maturity as treatments and four replications of 25 seeds, corresponding to collections made in April, May, June and July 2014. The data regarding germination percentage were subjected to regression analysis using the SISVAR (Ferreira, 2010) software.
For analysis of tolerance to desiccation, the results of the means of the treatments in the months of April and May were subjected to Student's t-test at 5\% significance. For analysis of seed dormancy, germination data from the aerial seed bank were used; the experiment was set up in a factorial arrangement with 2 dormancy treatments (with and without breaking dormancy) and 9 collection periods, with four replications of 25 seeds. The data on germination percentage, MGT, and percentage of dormant seeds in the aerial seed bank were subjected to Shapiro-Wilk normality testing. The germination, MGT, and dormant seed data not normalized were transformed to $\log (\mathrm{x})$; after normalization of the data, analysis of variance was carried out, and the means were subjected to regression analysis. The data were subjected to analysis of variance (ANOVA) and the means of the treatments were subjected to regression analysis at $5 \%$ probability with the aid of the SISVAR (Ferreira, 2010) statistical program.

\section{Results and Discussion}

The moisture content of the seeds decreased from the first to the second collection (April and May) from 66 to $13 \%$ and remained stable as of that point (Figure 1A). The results of analysis of variance indicated that there was the effect of collection times of the fruit on viability of the $P$. dubium seeds during their formation, which is observed upon comparing germination from collection in April 2014 (7\%) with collection in May, when mean germination was greater than $90 \%$ (Figure 1A).

In relation to tolerance to desiccation, it was observed that after drying the seeds, germination was 10\% (April); however, in the second collection, germination after drying was $99 \%$, indicating that as of the second collection (May), the seeds had already acquired tolerance to desiccation (Figure 1B). Thus, associating the data of seed physiological quality, it was considered in this study that seeds achieved physiological maturity in June, when the fruit had a dark brown color, and, from that time on, studies of the aerial seed bank were carried out.

During formation of $P$. dubium seeds, the difference in moisture content observed between the first two stages of maturity (Figure 1A) may have been due to the immaturity of the seeds, since the variation observed, which reduced over time, is typical of orthodox seeds before physiological maturity (Nakada et al., 2011; Ricci et al., 2013). Tolerance to desiccation is acquired during development and allows reduction in moisture content to occur without damage to seeds (Bewley et al., 2013; Garnczarska et al., 2009). In $P$. 
dubium seeds, it was found that acquisition of tolerance to desiccation occurred between April and May, which coincided with the increase in maximum germinability (Figure 1B). It addition, it is commonly observed that acquisition of tolerance to desiccation occurs before the seeds achieve their maximum germinability, as a manner of preparation for dispersal (Angelovici et al., 2010; Gojło et al., 2015).

Analyzing the data on moisture content, seed viability, and tolerance to desiccation, it can be concluded that physiological maturity occurred in June. Furthermore, other authors, such as Aquino et al. (2006) upon studying the physiological maturity of $P$. dubium, also found that the physiological maturity of the species under study occurs in June.

Analyzing the results of germination of $P$. dubium seeds in

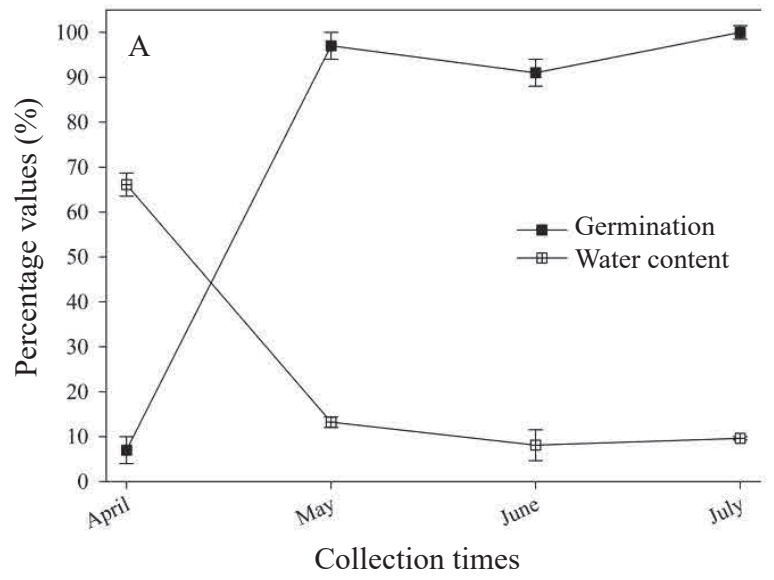

the aerial seed bank (June 2014 to February 2015), no significant effect $(F=0.05 ; p \leq 0.05)$ was found of the collection times of fruit on the viability of $P$. dubium seeds. Collected seeds showed viability higher than $90 \%$ (Figure $2 \mathrm{~A}$ ).

No significant effect $(\mathrm{F}=0.05 ; \mathrm{p} \leq 0.05)$ was observed of the collection times on dormancy of $P$. dubium seeds; that is, there was no natural breaking of seed dormancy during the period within the aerial seed bank. The mean percentage of dormant seeds during the period of study was greater than $84 \%$ (Figure 2A).

In regard to moisture content of the seeds over the period they remained in the aerial seed bank, there were small variations between June 2014, at 7.7\%, and February 2015, at $8.1 \%$ (Figure $2 \mathrm{~A}$ ), maintaining practically stable values

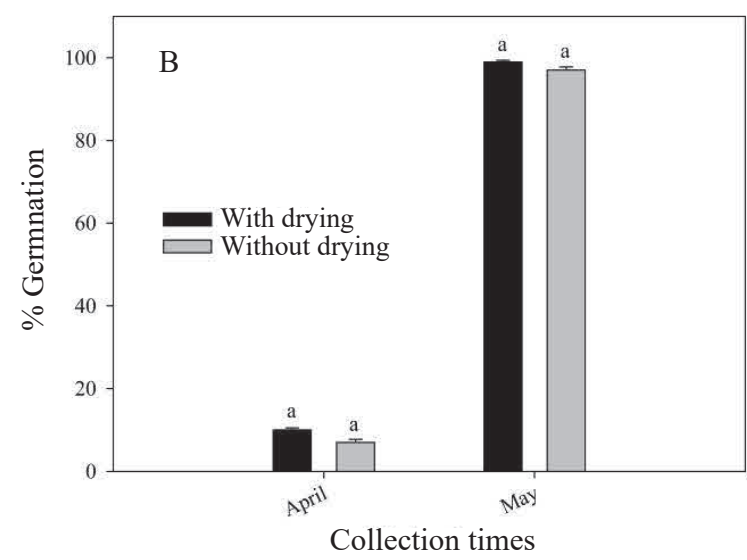

Figure 1. A - Germination (\%) and moisture content during P. dubium seed formation from April 2014 to July 2014 . B Acquisition of tolerance to desiccation during development of $P$. dubium seeds. The bars represent standard deviation from the mean.

*Means followed by the same letter in each collection time do not differ among themselves by Student's t-test at 5\% probability.
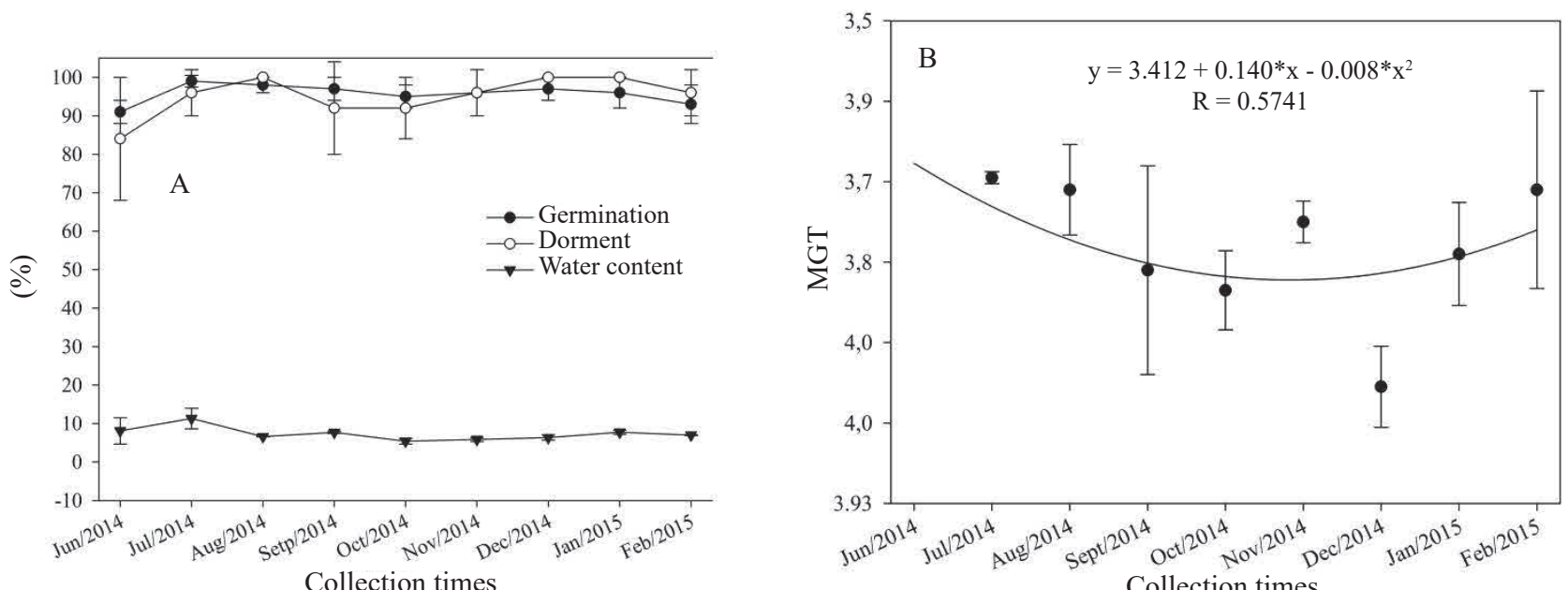

Figure 2. A - Germination (\%), dormant seeds (\%), moisture content of $P$. dubium seeds in the aerial seed bank. B - MGT of $P$. dubium seeds in the aerial seed bank. The bars represent the standard deviation from the mean. 
throughout the experimental period.

There was a significant effect for mean germination time of the aerial seed bank $(F=0.05 ; p \leq 0.05)$, with the longest MGT registered in July 2014, at four days; in contrast, the shortest MGT was registered in December 2014, at three days and a half (Figure 2B).

It was observed that the seeds maintained viability throughout the period they remained in the aerial seed bank. Most of the fruits promptly disperse all their seeds upon reaching maturity so that the seeds encounter favorable conditions to germination or otherwise are incorporated in the soil seed bank (Long et al., 2015). Generally, after reaching physiological maturity, seeds are subject to environmental variations (moisture and temperature) and begin a natural deterioration process, culminating in loss in vigor (Baskin and Baskin, 2014).

According to observations made in this study, the species $P$. dubium forms an aerial seed bank, with fruits remaining attached to the plant for a period of up to nine months, which may be classified as short serotiny (Lamont et al., 1991).

In Brazil, the only species described as forming an aerial seed bank was Parkia pendula, which maintains fruits attached to the plants for up to six months (Oliveira et al., 2006). It is known that there are few studies related to aerial seed banks in Brazil; however, P. dubium is the first native species of the semideciduous seasonal forest to be described with this type of activity.

Studies related to aerial seed banks in general report the absence of seed dormancy throughout the period of seed dispersal (Kim et al., 2009; Baskin and Baskin, 2014). Nevertheless, this was not observed in P. dubium, for which no change in physical dormancy of the seeds was observed over their time within the aerial seed bank (Figure 2A).

When dormant seeds are exposed to environmental variations such as oscillations in temperature and moisture, dormancy may be broken (Jha et al., 2015; Newton et al., 2015) moist temperate woodland species Galanthus nivalis and Narcissus pseudonarcissus are complex and poorly understood. Temperature, light and desiccation were investigated to elucidate their role in the germination ecophysiology of these species. The effect of different seasonal temperatures, seasonal durations, temperature fluctuations, the presence of light during different seasons and intermittent drying (during the summer period). The lack of variations in physical dormancy of $P$. dubium seeds during the period in the seed bank may indicate that these environmental variations are insufficient to change the physical dormancy of $P$. dubium, and may ensure that germination be delayed until there are favorable conditions for germination and seedling establishment (Dalling et al., 1998). This contributes to the formation of the soil seed bank, with continuous inputs of seeds during the period in which seeds are being dispersed in the aerial seed bank.

The climate variations observed during the period of study indicate the influence of variations of temperature and rainfall on the physiological quality of the seeds over the time they remain attached to the mother plant. Within the period of April 2014 to February 2015, the lowest rainfall amount was in June 2014 (3.7 mm); in contrast, the greatest amount was in November 2014 (249.4 mm) (Figure 3). This may suggest that $P$. dubium has the ability to adapt and establish itself in environments with contrasting conditions without harm to the physiological quality of its seeds (Dürr et al., 2015).

The MGT indicated that, apart from the effect of climate variations on the aerial seed bank, there was a reduction in MGT up to the seventh month (December 2014) after characterization of the aerial seed bank. For some authors (Mavi et al., 2010; Soltani and Baskin, 2015), the MGT may be correlated with field emergence, in which the shorter the MGT, the greater the chances of seedling establishment. Thus, reduction in the MGT of the $P$. dubium species showed that although maturity occurred in June, the quality of the seeds evaluated by this variable increased; it is noteworthy that the shortest value of MGT occurred in the rainiest period (Figure 2B).

Throughout the period of seed formation and time in the aerial seed bank (March 2014 to February 2015), the protein profile exhibited small changes related to the accumulation of total and heat-resistant proteins. High intensity bands

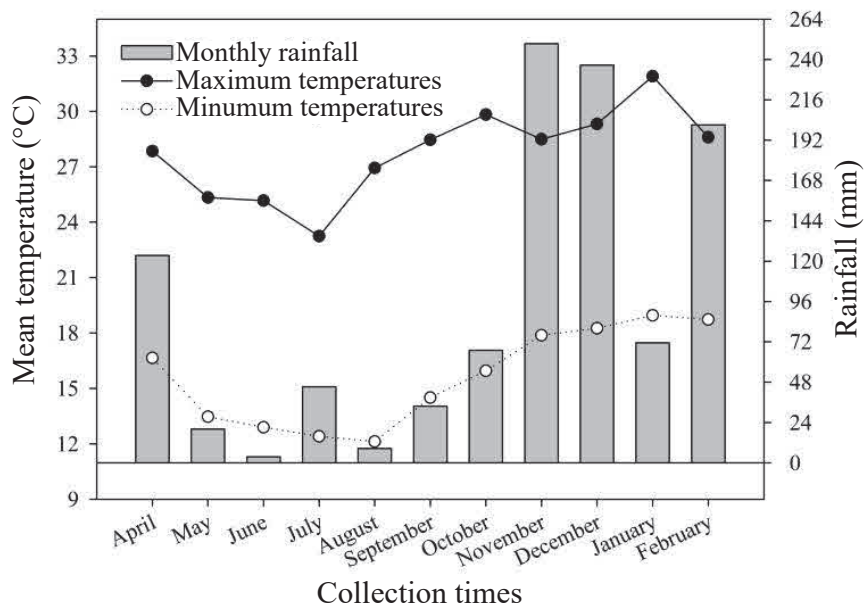

Figure 3. Climatological variations (maximum and minimum temperatures and rainfall) in the period from April 2014 to February 2015. Source: data obtained from the climatological station of UFLA. 


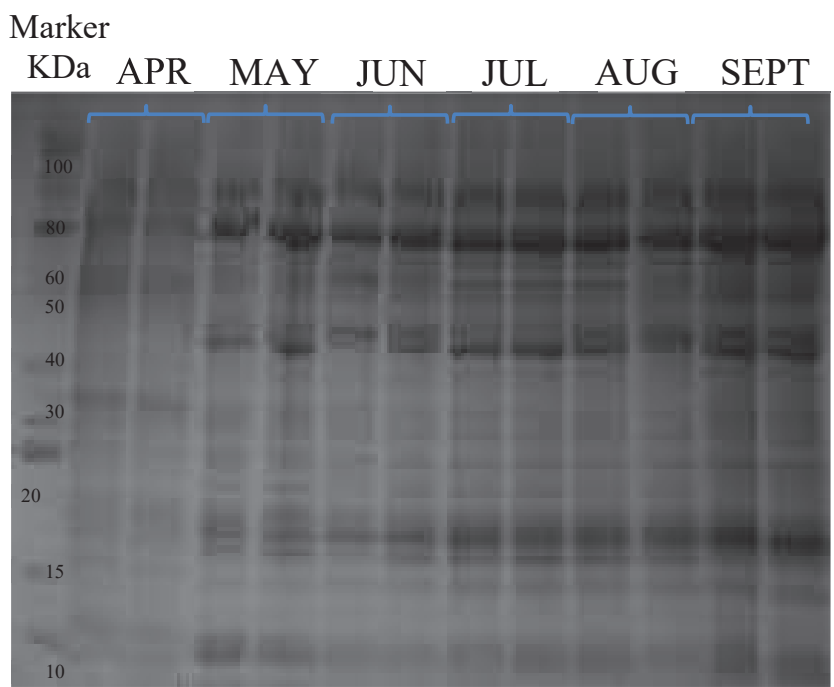

Total proteins

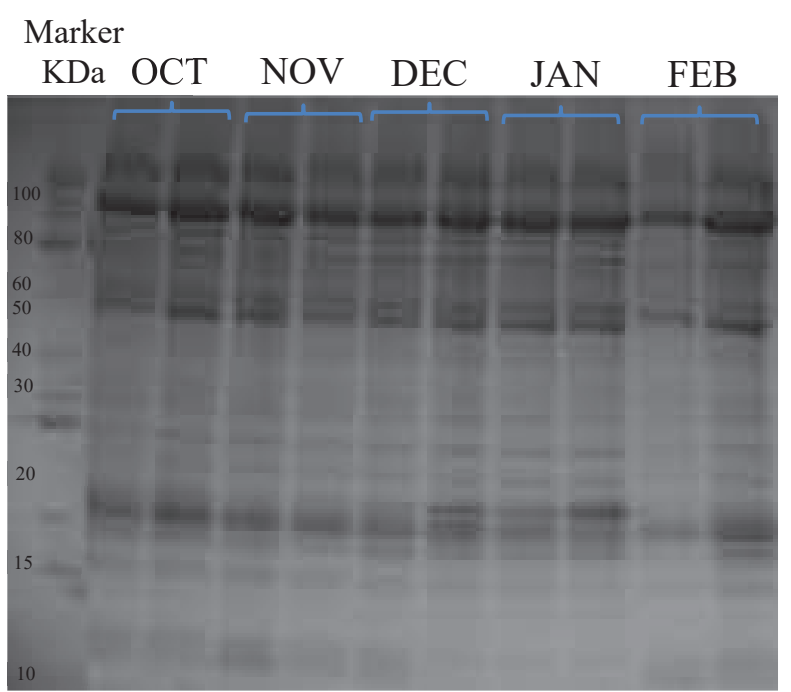

Total proteins

Figure 4. Electrophoretic pattern of total proteins extracted from P. dubium from April 2014 to February 2015. Intensity of the bands represents concentration of total proteins in their respective molecular weight (KDa).

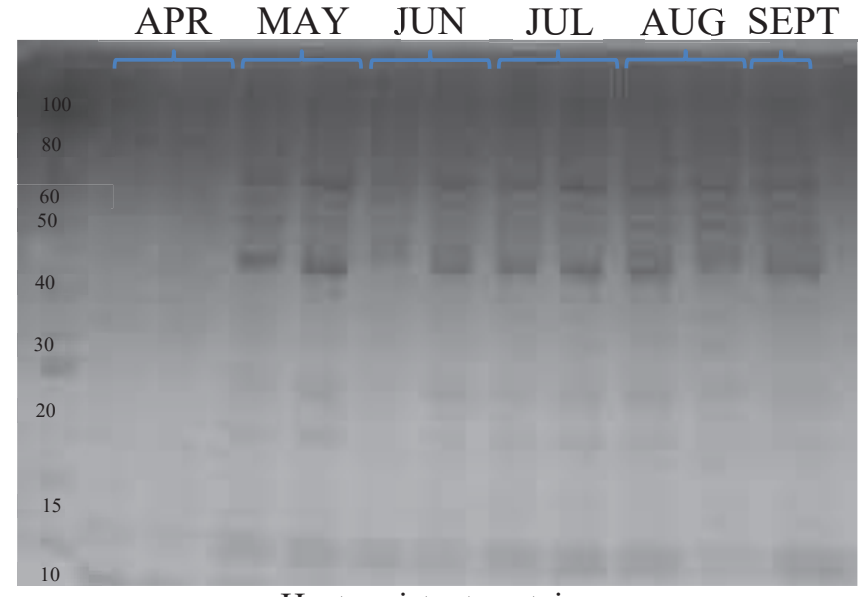

Heat-resistent proteins

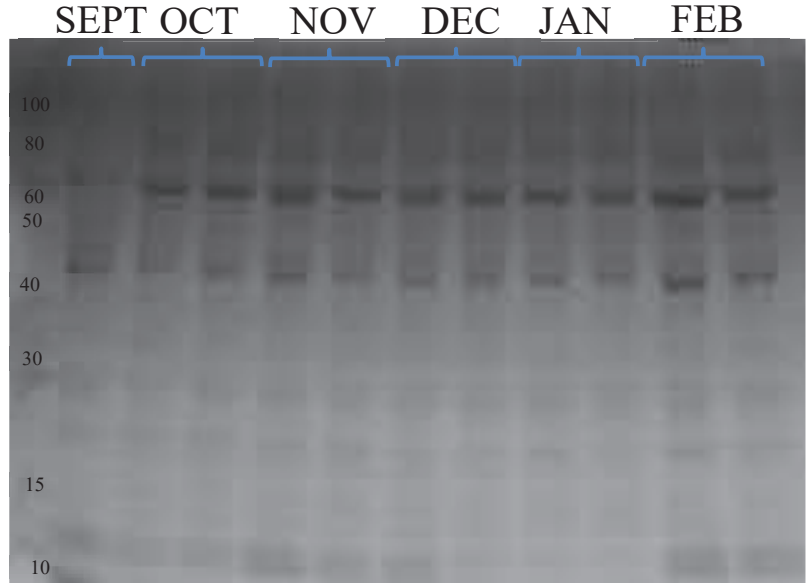

Heat-resistent proteins

Figure 5. Electrophoretic pattern of heat-resistant proteins extracted from P. dubium from April 2014 to February 2015. Intensity of the bands represents concentration of heat-resistant proteins in their respective molecular weight (KDa).

were observed throughout the gel $(10-100 \mathrm{KDa})$ when total proteins are analyzed (Figure 4); however, for the heatresistant proteins, greater concentrations were observed between 40 and $80 \mathrm{KDa}$ (Figure 5). During the period of seed maturation (between the collections of April and May 2014), the accumulation of total proteins and heat-resistant proteins is observed, shown by less visible bands in the gel in this period, and, as already observed by physiological data, the seeds had not yet reached physiological maturity, which occurred in June 2014.

Metabolic events that occur during maturation have the purpose of preparing the seed for its germination and, consequently, development of the seedling (Thomas, 1993;
Kalemba and Pukacka, 2008). The increase in the concentration of proteins and other compounds during development and their maintenance after physiological maturity is important, especially when dealing with seeds that remain for a long period apart from the mother plant, as in serotinous species (Santini and Martorell, 2013). Maintenance of protein content is associated with low metabolic activity, as a result of reduction in moisture content during development and by the low activity of proteases, and by maintenance of the apparatus that impedes damage caused by reactive oxygen species and free radicals (Murthy et al., 2003).

As the main components of seed reserves of various leguminous plants, proteins are used for maintenance of seed 
vigor (Wang et al., 2015a; Wang et al., 2015b; Wu et al., 2011) until their dispersal, as of which time, reduction in protein content may occur (Kalemba and Pukacka, 2008). However, such a response cannot be observed in this study, which would indicate low metabolic activity and, consequently, maintenance of the protein concentration in the aerial seed bank. Another indication of low metabolic activity and low consumption of reserves would be the maintenance of seed vigor after formation of the aerial seed bank up to the last period of evaluation in February 2015.

\section{Conclusions}

P. dubium is a species that forms an aerial seed bank of short serotiny.

During the period that fruits remain in the aerial seed bank, there are no changes in the physiological quality of the seeds of the species $P$. dubium.

\section{References}

ALBUQUERQUE, L.B.; ALONSO, A.M.; AQUINO, F.G.; REATTO, A.; SOUSA-SILVA, J.C.; LIMA, J. E. F. W.; SOUSA, A.C.S.A.; SOUSA, E. S. Restauração ecológica de matas ripárias: uma questão de sustentabilidade. Embrapa Cerrados Documentos 295, 2010. 77p. http://www.cpac.embrapa.br/download/1922/t

ANGELOVICI, R; GALILI, G.; FERNIE, A.R.; FAIT, A. Seed desiccation: a bridge between maturation and germination. Trends in Plant Science, v.15, n.4, p.211-218, 2010. http://www.ncbi.nlm.nih. gov/pubmed/20138563

AQUINO, N.F.; BORTOLINI, M.; CAMPAGNOLO, M.A.; IGNÁCIO, V.L.; KOPPER, A.C.; MALAVASI, M.M. Dormência de sementes de Peltophorum dubium (Sprengel.) Taubert colhida em diferentes estádios de desenvolvimento. Scientia Agraria Paranaensis, v.5, n.2, p.31-37, 2006. http://e-revista.unioeste.br/ index.php/scientiaagraria/article/view/2025/1600

BASKIN, J.M.; BASKIN, C.C. Seeds: Ecology, Biogeography, and Evolution of dormancy and Germination. Cambridge: Cambridge University Press, v.1, p. 1-1601, 2014.

BASTIDA, F.; GONZALÉZ- ANDÚJAR, J.L.; MONTEAGUDO, J.M.; MENÉNDEZ, J. Aerial seed bank dynamics and seedling emergence patterns in two annual Mediterranean Asteraceae. Journal of Vegetation Science, v.21, p.541-550, 2010. http://onlinelibrary. wiley.com/doi/10.1111/j.1654-1103.2010.01169.x/full

BERTOLINI, I.C.; BRUN, E.J.; DEBASTIANI, A.B. Caracterização silvicultural da canafístula (Peltophorum dubium (Sprengel) Taubert). Scientia Agraria Paranaensis, v.14, n.2, p.67-76, 2015. http://e-revista.unioeste.br/index.php/scientiaagraria/article/ view/9842/8547.
BEWLEY, J.D.; BRADFORD, K.J.; HILHORST, H.W.M.; NONOGAKI, H. Seeds: physiology of development, germination and dormancy. 3ed. New York: Springer, 2013. 395p.

BRADFORD, M.M. A rapid and sensitive method for the quantitation of microgram quantities of protein utilizing the principle of protein-dye binding. Analytical Biochemistry, v.72, n. 1-2, p. 248-254, 1976. http://www.sciencedirect.com/science/article/ pii/0003269776905273

BRAGA, A.J.T.A.; BORGES, E.E L.; MARTINS, S.V. Chuva de sementes em estádios sucessionais de floresta semidecidua. Revista Árvore, p.475-485, 2015. http://www.scielo.br/pdf/rarv/ v39n3/0100-6762-rarv-39-03-0475.pdf

BRASIL. Ministério da Agricultura, Pecuária e Abastecimento. Regras para análise de sementes. Ministério da Agricultura, Pecuária e Abastecimento. Secretaria de Defesa Agropecuária. Brasília, DF: MAPA/ACS, 2009. 395p. http://www.agricultura.gov.br/arq_editor/ file/2946_regras_analise_sementes.pdf

DALLING, A. J.W.; HUBBELL, S.P.; SILVERA, K. Seed dispersal, seedling establishment and gap partitioning among tropical pioneer trees. Society, v.86, n.4, p.674-689, 1998. http://sirismm.si.edu/ctfs/ Dallingetal1998JourEcol.pdf

DURIGAN, G.; MELO, A.C.G.; MAS, J.C.M.; BOAS, O.V.; CONTIERI, W.A.; RAMOS, V.S. Manual para recuperação da vegetação de Cerrado. 3. ed. São Paulo: Páginas e Letras, 2011. 19p. http://www.sigam.ambiente.sp.gov.br/sigam3/Repositorio/222/ Documentos/Manual_recuperacao_cerrado.pdf

DÜRR, C.; DICKIEB, J.B.; YANGC, X.Y.; PRITCHARD, H.W. Agricultural and Forest Meteorology Ranges of critical temperature and water potential values for the germination of species worldwide : Contribution to a seed trait database. Agricultural and Forest Meteorology, v.200, p. 222-232, 2015. http://www.sciencedirect. com/science/article/pii/S0168192314002482

FERREIRA, D.F. SISVAR - Sistema de análise de variância. Versão 5.3. Lavras-MG: UFLA, 2010. http://www.dex.ufla.br/ danielff/ programas/sisvar.html

GAO, R.; YANG, X.; YANG, F.; WEI, L.; HUANG, Z.; WALCK, J.L. Aerial and soil seed banks enable populations of an annual species to cope with an unpredictable dune ecosystem. Annals of Botany, v.114, p.279-287, 2014. http://aob.oxfordjournals.org/ content/early/2014/06/10/aob.mcu104.short

GARNCZARSKA, M.; BEDNARSKI, W.; JANCELEWICZ, M. Ability of lupine seeds to germinate and to tolerate desiccation as related to changes in free radical level and antioxidants in freshly harvested seeds. Plant Physiology and Biochemistry, v.47, n.1, p.56-62, 2009. http://www. ncbi.nlm.nih.gov/pubmed/?term=Ability+of+lupine+seeds+to+germinate + and + to + tolerate + desiccation + as + related + to + changes + in + free + radical+level+and+antioxidants + in + freshly + harvested + seeds. + Plant + Physiology+and+Biochemistry $\% 2 \mathrm{C}$ 
GOJŁO, E.; PUPEL, P.; LAHUTA, L.B.; KUCEWICSZ, M; GORECKI, R.J. The acquisition of desiccation tolerance in developing Vicia hirsuta seeds coincides with an increase in galactinol synthase expression and soluble $\alpha$-d-galactosides accumulation. Journal of Plant Physiology, v.184, p.37-48, 2015. http://www.ncbi.nlm.nih.gov/pubmed/?term=The+acquisition + of + desiccation+tolerance + in + developing + Vicia + hirsu$\mathrm{ta}+$ seeds + coincides + with + an + increase + in + galactinol + synthase + expression + and + soluble $+\% \mathrm{CE} \% \mathrm{~B} 1$-d-galactosides + accumulation.+ Journal+of+Plant+Physiology $\% 2 \mathrm{C}$

GUIMARÃES, S.; MARTINS, S.V.; NERI, A.V.; GLERIANI, J.M.; SILVA, K.A. Banco de sementes de áreas em restauração florestal em Aimorés, MG. Pesquisa Florestal Brasileira, v. 34, n. 80, p. 1-12, 2014. https://pfb.cnpf.embrapa.br/pfb/index.php/pfb/article/ view $/ 437 / 383$

JHA, P.; NORSWORTHY, J. K.; KUMAR, V.; REICHARD, $\mathrm{N}$. Annual changes in temperature and light requirements for Ipomoea purpurea seed germination with after-ripening in the field following dispersal. Crop Protection, v.67, p.84-90, 2015. https://www.infona.pl/resource/bwmeta1.element.elseviercd02c4cd-8c27-358a-8c00-4e695221ff88

KALEMBA, E. M.; PUKACKA, S. Changes in late embryogenesis abundant proteins and a small heat shock protein during storage of beech (Fagus sylvatica L.) seeds. Environmental and Experimental Botany, v.63, p.274-280, 2008. http://www.academia.edu/18419314/Changes in late embryogenesis_abundant_proteins_and_a_small_heat_shock_ protein_during_storage_of_beech_Fagus_sylvatica_L._seeds

KIM, J.H.; WALCK, J.L.; HIDAYATI, S.N.; MERRITT, D.J.; DIXON, K.W. Germinability of seeds stored in capsules on plants of two myrtaceous shrubs: differences among age cohorts and between species. Australian Journal of Botany, v.57, n.6, p.495501, 2009. https://www.academia.edu/10134661/Germinability_of_ seeds_stored_in_capsules_on_plants_of_two_myrtaceous_shrubs differences_among_age_cohorts_and_between_species

LABOURIAU, L.G. A germinação das sementes. Washington: Secretaria Geral da Organização dos Estados Americanos, 1983. 174 p.

LORENZI, H. Árvores brasileiras: manual de identificação e cultivo de plantas arbóreas do Brasil. Nova Odessa: Plantarum, 2002. 384 p.

LAMONT, B.B.; LE MAITRE, D.C.; COWLING, R.M.; ENRIGHT, N.J. Canopy Seed Storage in Woody Plants. The Botanical Review, v.57, n.4, p.277-317, 1991. http://link.springer.com/article/10.1007/ BF02858770

LONG, R.L.; GORECKI, M.J.; RENTON, M.; SCOTT, J.K.; COLVILLE, L.; GOGGIN, D.E.; COMMANDER, L.E.; WESTCOTT, D.A.; CHERRY, H.; FINCH-SAVAGE, W.E. The ecophysiology of seed persistence: a mechanistic view of the journey to germination or demise. Biological Reviews, v.90, p.31-59, 2015. https://www.researchgate.net/profile/Michael Renton/publication/260717007_The_ecophysiology_of_seed_ persistence_A_mechanistic_view_of_the_journey_to_germination or_demise/links/54360ca00cf2643ab986a3a7.pdf
MAVI, K.; DEMIR, I.; MATTHEWS, S. Mean germination time estimates the relative emergence of seed lots of three cucurbit crops under stress conditions. Seed Science and Technology, v. 38, p. 14-25, 2010. https://www.researchgate.net/profile/Kazim Mavi2/publication/233712444_Controlled_deterioration_and accelerated_ageing_tests_to_predict_seedling_emergence_of watermelon under stressful_conditions and seed longevity/ links/0912f50af5f927543c000000.pdf

MIRANDA NETO, A.M.; KUNZ, S.H.; MARTINS, S.V.; SILVA, K.A.; SILVA, D.A. Transposição do banco de sementes do solo como metodologia de restauração florestal de pastagem abandonada em Viçosa, MG. Revista Árvore, v.34, n.6, p.1035-1043, 2010. http://files.pereiraim.webnode.com.br/200000044f40eb00e4b/ transposi $\% \mathrm{C} 3 \% \mathrm{~A} 7 \% \mathrm{C} 3 \% \mathrm{~A} 3 \mathrm{o} \% 20 \mathrm{de} \% 20$ solo.pdf

MURTHY, U.M.; KUMAR, P.P.; SUN,W.Q. Mechanisms of seed ageing under different storage conditions for Vigna radiata (L.) Wilczek: lipid peroxidation, sugar hydrolysis, Maillard reactions and their relationships to glass state transition. Journal of Experimental Botany, v.54, p.1057-1067, 2003. http://jxb.oxfordjournals.org/ content/54/384/1057.short

NAKADA, P.G.; OLIVEIRA, J.A.; MELO, L.C.; GOMES, L.A.; VON PINHO, E.V.R. Desempenho fisiológico e bioquímico de sementes de pepino nos diferentes estádios de maturação. Revista Brasileira de Sementes, v.33, n.1, p.113-122, 2011. https://www.researchgate.net/profile/Pamela_Nakada_Freitas/ publication/263779444 Desempenho fisiologico_e bioquimico de_sementes_de_pepino_nos_diferentes_estadios_de_maturacao/ links/0f31753be538d97556000000.pdf

NEWTON, R.J.; HAY, F.R.; ELLIS, R.H. Ecophysiology of seed dormancy and the control of germination in early spring-flowering Galanthus nivalis and Narcissus pseudonarcissus (Amaryllidaceae). Botanical Journal of the Linnean Society, v.177, n.2, p.246-262, 2015. http://onlinelibrary.wiley.com/doi/10.1111/boj.12240/full

OLIVEIRA, P.M.C.O.; FERRAZ, I.D.K.; OLIVEIRA, G.J. Dispersão e superação da dormência de sementes de Parkia pendula ( Willd .) Walp . (visgueiro) na Amazônia Central , AM , Brasil. Hoehnea, v.33, n.4, p.485-493, 2006.

RICCI, N.; PACHECO, A.C.; CONDE, A.S.; CUSTÓDIO, C. Qualidade de sementes de pimenta jalapenho em função da maturação e tempo de permanência nos frutos. Pesquisa Agropecuaria Tropical, v.43, n.2, p.123-129, 2013. https://www.researchgate.net/profile/ Ana Pacheco5/publication/262747252 Seed quality of jalapeno pepper_according_to_fruit_maturation_and_post_harvest_rest/ links/0f3̈1753c430a1b3 $\bar{c} 35000000 . p d f$

SANTINI, B.A.; MARTORELL, C. Does retained-seed priming drive the evolution of serotiny in drylands?: an assessment using the cactus Mammillaria hernandezii. American Journal of Botany, v.100, n.2, p.365-373, 2013. http://www.amjbot.org/content/100/2/365.full

SILVA, K.B.; ALVES, E.U.; BRUNO, R.L.A.; SANTOS, S.S.; BARROSO, L.M. Tolerância à dessecação de sementes de Cinnamomum zeylanicum Ness. Semina: Ciências Agrárias, v.33, n.2, p.587-594, 2012. http://www.uel.br/revistas/uel/index.php/ semagrarias/article/view/6504 
SOLTANI, E.; BASKIN, C. Problems with using mean germination time to calculate rate of seed germination. Australian Journal of Botany, v.63, n.8, p.631-635, 2015. http://agris.fao.org/agris-search/ search.do?recordID=US201600092030

TESTE, F.P.; LIEFFERS, V.J.; LANDHÄUSSER, S.M. Viability of forest floor and canopy seed banks in Pinus contorta var. latifolia (Pinaceae) forests after a mountain pine beetle outbreak. American Journal of Botany, v.98, n.4, p.630-637, 2011. http://www.amjbot. org/content $/ 98 / 4 / 630$.short

THOMAS, T.L. Gene expression during plant embryogenesis and germination: an overview. The Plant Cell, v.5, n.10, p.1401-1410, 1993. http://www.ncbi.nlm.nih.gov/pmc/articles/PMC160371/pdf/051401.pdf

TONELLO, K.C.; TEIXEIRA FILHO, J. Ecofisiologia de três espécies arbóreas nativas da mata atlântica do brasil em diferentes regimes de água. Irriga, v.17, n.1, p.85-101, 2012. http://irriga.fca. unesp.br/index.php/irriga/article/view/389/210
WANG, G.D.; WANGA, M.; LU, X.; JIANG, M. Effects of farming on the soil seed banks and wetland restoration potential in Sanjiang Plain, Northeastern China. Ecological Engineering, v.77, p.265274, 2015a. http://www.sciencedirect.com/science/article/pii/ S0925857415000622

WANG, W. Q.; LIU, S.J.; SONG, S. Q.; MØLLER, I. M. Proteomics of seed development, desiccation tolerance, germination and vigor Plant Physiology and Biochemistry, v.86, p.1-15, 2015b. http:// www.sciencedirect.com/science/article/pii/S0981942814003362

WENK, E. H.; FALSTER, D.S. Quantifying and understanding reproductive allocation schedules in plants. Ecology and evolution, v.5, n.23, p.5521-5538, 2015. http://europepmc.org/articles/pmc4813122

WU, X.; LIU, H.; WANG, W.; CHEN, S.; HU, X.; LI, C. Proteomic analysis of seed viability in maize. Acta Physiologiae Plantarum, v.33, n.1, p.181-191, 2011. http://link.springer.com/article/10.1007/ s11738-010-0536-4 